\title{
Lung Is an Important Source of Atrial Natriuretic Factor in Experimental Cardiomyopathy
}

\author{
Jolanta Gutkowska, ${ }^{*}$ Mona Nemer, ${ }^{*}$ Michael J. Sole, ${ }^{\ddagger}$ Jacques Drouin, ${ }^{*}$ and Pierre Sirois ${ }^{\mathbf{5}}$ \\ *Institut de Recherches Cliniques de Montréal, Montreal, Quebec, Canada H2W 1R7; ${ }^{\ddagger}$ Department of Medicine, Division of \\ Cardiology, Toronto General Hospital, Toronto, Ontario, Canada M5G 2C4; and ${ }^{\S}$ Département de Pédiatrie et de Pharmacologie, \\ Faculté de Médecine, Université de Sherbrooke, Sherbrooke, Quebec, Canada JIK 2RI
}

\begin{abstract}
The regulation of water and electrolyte homeostasis is multifactorial and includes the heart and kidneys as important regulatory centers. Within the heart, a recently discovered hormone, atrial natriuretic factor (ANF), has been implicated in the maintenance of water and salt balance. Primarily found in mammalian atria, ANF has been detected in low amounts in several tissues, including lungs. A disorder of the ANF system has been demonstrated in genetically cardiomyopathic hamsters, a model for human congestive cardiomyopathy. Atrial ANF gene expression and storage are decreased during development of this disease, while paradoxically, circulating levels of ANF are increased. We have hypothesized that an extracardiac source may contribute to ANF production in these pathological conditions. In this paper we provide evidence that ANF synthesis is stimulated in the lungs of hamsters during development of cardiomyopathy as revealed by increased ANF mRNA and peptide levels. Furthermore, we show that ANF synthesized in lungs is secreted and has identical chromatographic and biological properties to circulating ANF. The increased production of ANF in lungs may be physiologically important in preventing pulmonary edema. Alternatively, during cardiac dysfunction, lungs may play a compensatory role by increasing their contribution to plasma ANF levels.
\end{abstract}

\section{Introduction}

The regulation of water and electrolyte homeostasis is under multifactorial control; some factors are responsible for the behavioral patterns of water and salt intake, while others are involved in the regulation of fluid and electrolyte retention of excretion (1). Many organs, including the heart, contribute to the maintenance of water and salt balance. Within the heart, atrial natriuretic factor (ANF), ${ }^{1}$ a 28 amino acid peptide hormone that is released from atria after activation of stretch receptors, and perhaps other hormonal signals, appears to play an important role in the regulation of water and electrolyte

Address correspondence to Dr. Jolanta Gutkowska, Institut de Recherches Cliniques de Montréal, 110 Avenue des Pins Ouest, Montreal, Quebec, Canada H2W 1 R7.

Received for publication 29 June 1988 and in revised form 27 October 1988

1. Abbreviations used in this paper: $\mathrm{ANF}$, atrial natriuretic factor; RP, reverse phase; TFA, trifluoroacetic acid.

J. Clin. Invest.

(C) The American Society for Clinical Investigation, Inc.

$0021-9738 / 89 / 05 / 1500 / 05 \$ 2.00$

Volume 83, May 1989, 1500-1504 balance in concert with other hormonal systems such as renin, angiotensin, aldosterone, and vasopressin $(2,3)$. First isolated from mammalian atria, ANF has also been found, albeit at much lower levels, in other tissues including ventricles, brain, pituitary, adrenals, and lungs (4). The presence of ANF prohormone (5) and mRNA (6) in normal rat lungs, together with our observation that rat lungs secrete biologically active ANF (5), suggest that lungs may be a physiologically relevant source of circulating ANF under certain conditions. We tested this hypothesis using genetically cardiomyopathic hamsters, a model of human congestive heart failure and a paradigm of hereditary dystrophy-like cardiopathy and myopathy (7). Cardiomyopathic hamsters have been shown to be deficient in atrial ANF bioactivity (8) with a corresponding reduction in ANF mRNA levels (9), suggesting that ANF gene expression is deficient in the atria of these animals. Paradoxically, plasma ANF levels are markedly increased (10). These data cannot be reconciled solely by an increased secretion leading to a subsequent reduction in storage in the atria (11). These observations suggest that an extra atrial source of ANF may develop during congestive heart failure. One such source appears to be the ventricular myocardium (12). In this study we show that the lung may be another, and particularly important, source.

\section{Methods}

Animals. The cardiomyopathic hamsters (TO.2) used in this study were originally derived from BIO 53.58 cardiomyopathic hamsters (13) and have been inbred for over 20 generations. The animals were housed at room temperature in a 12-h light-dark cycle and fed normal chow. They drank water ad lib.

Three major groups of hamsters were studied. Young animals (106 d old) exhibited the myocardial lesions characteristic of cardiomyopathy, but had minimal hypertrophy and no evidence of congestion. Animals 163 and $217 \mathrm{~d}$ old were characterized by increasing ventricular hypertrophy and occasional mild hepatic congestion. Animals 252 and $272 \mathrm{~d}$ old had advanced cardiomyopathy, with cardiac dilatation, pulmonary and hepatic congestion, and subcutaneous edema. Random bred Syrian golden hamsters were used as a control.

Preparation of tissue homogenates. The animals were killed by decapitation. Lungs from each animal were immediately dissected and after washing in saline they were collected in $5 \mathrm{ml}$ cold $0.1 \mathrm{M}$ acetic acid containing protease inhibitors to a final concentration of $1 \mathrm{mg}$ EDTA/ml, $5 \mu$ M pepstatin A (No. P4265; Sigma Chemical Co., St. Louis, MO), and $10 \mu \mathrm{M}$ PMSF (No. P7626; Sigma Chemical Co.). The tissue was homogenized at $4^{\circ} \mathrm{C}$ for $30 \mathrm{~s}$ in a Polytron homogenizer. After 20 min centrifugation at $32,000 \mathrm{~g}$ the pellet was washed and rehomogenized in 2.5 acetic acid containing inhibitors. Both supernatants were collected together. Right and left atria were also quickly dissected and separately collected in $2 \mathrm{ml} 0.1 \mathrm{M}$ acetic acid with inhibitors. The same procedure as described for lungs was followed. The ANF immunoreactivity was determined by direct RIA as previously described (14). 
Extraction of ANF from plasma and tissues. After decapitation, trunk blood was collected in chilled tubes containing $1 \mathrm{mg}$ EDTA, 10 $\mu \mathrm{l}$ pepstatin A $0.510^{-3} \mathrm{M}$, and $10 \mu \mathrm{l}$ PMSF $10^{-3} \mathrm{M} / \mathrm{ml}$ of blood and centrifuged at $3,500 \mathrm{rpm}$ for $20 \mathrm{~min}$ at $4^{\circ} \mathrm{C}$. The plasma was assayed immediately or stored at $-70^{\circ} \mathrm{C}$. The ANF was extracted from plasma by heat-activated glass beads (Vycor; Corning Glass Works, Corning, NY) (15). To $1 \mathrm{ml}$ of hamster plasma, $0.5 \mathrm{ml}$ of activated glass suspension (Vycor; $50 \mathrm{mg}$ in $1 \mathrm{ml}$ distilled water) was added and agitated slowly in a cold room $\left(4^{\circ} \mathrm{C}\right)$ for $30 \mathrm{~min}$. After $3 \mathrm{~min}$ centrifugation at $3,000 \mathrm{rpm}$ the supernatant was aspirated and the glass powder was washed with $1.5 \mathrm{ml}$ deionized water. The adsorbed ANF was eluted from the glass powder with $1 \mathrm{ml}$ of $60 \%$ acetone in $0.05 \mathrm{M} \mathrm{HCl}$. The acetone was evaporated in a nitrogen stream and the aqueous phase was lyophilized in a Speed-Vac. Just before the assay the residue was dissolved in RIA buffer.

For further purification on reverse phase (RP)-HPLC, tissue ANF was extracted from homogenates on Sep-Pak cartridges that were activated by 8-10 $\mathrm{ml}$ acetonitrile and then washed with 8-10 $\mathrm{ml}$ ammonium acetate, $\mathrm{pH}$ 4.0. The adsorbed ANF was eluted with $3 \mathrm{ml} 60 \%$ acetonitrile in ammonium acetate $(0.2 \%, \mathrm{pH} 4.0)$. The organic solvent was evaporated under a nitrogen stream followed by lyophilization in a Speed-Vac (16).

RIA for $A N F$. ANF immunoreactivity was determined by a double antibody RIA (14). The sensitivity of this assay was $\sim 0.75 \mathrm{pg}$.

Reverse phase HPLC. The lyophilized tissue extracts were dissolved in $10 \%$ acetonitrile and $0.1 \%$ trifluoroacetic acid (TFA) and injected on a $\mathrm{C}_{18} \mu \mathrm{m}$ Bondapak column $(3.9 \mathrm{~mm} \times 30 \mathrm{~cm})$ in a $(\mathrm{LKB}$ Instruments, Inc., Gaithersburg, MD) HPLC system. The elution of ANF from the column was performed with a linear gradient of $15-50 \%$ acetonitrile in $0.1 \%$ TFA at a flow rate of $1 \mathrm{ml} / \mathrm{min}$. The $2-\mathrm{ml}$ fractions were collected. ANF immunoreactivity was determined by direct RIA (14).

$R N A$ analysis. Animals were killed by decapitation and lungs, ventricles, and atria were dissected and quickly frozen in liquid nitrogen. Measurements were performed on two groups, each consisting of 10 controls and 5 cardiomyopathic animals. Total RNA was extracted and processed for Northern blot hybridization as previously described (17) using a ${ }^{32} \mathrm{P}$-labeled 600-bp Pst I fragment of rat ANF cDNA (18). The amount of total RNA was quantitated using ultraviolet spectroscopy, and the integrity of the RNA was checked by agarose gel electrophoresis. The amount of total mRNA in each RNA sample was evaluated by dot blot hybridization to a ${ }^{32} \mathrm{P}$-labeled oligo(dT) $)_{12-18}$ probe. Finally, a rat brain $\beta$-actin cDNA probe (19) was used as internal control in rehybridization experiments. The amount of specific mRNA species was quantitated by densitometric scanning of the autoradiographs. No significant change in the level of $\beta$ and $\gamma$ actin mRNAs was observed among the different groups.

Hamster lung perfusion. Hamsters were anesthetized with an intraperitoneal injection of pentobarbital $(1.6 \mathrm{mg} / 100 \mathrm{~g}$ body $\mathrm{wt})$ after they were killed, and the lungs perfused according to the technique of Engineer et al. (20) as we have previously described. Briefly, the heart and lungs were totally removed and rapidly perfused with oxygenated Krebs buffer via pulmonary artery. The lungs were perfused initially at a rate of $10 \mathrm{ml} / \mathrm{min}$ and inflated several times to eliminate all traces of blood. After the cannula inside the pulmonary artery was tied, the heart was discarded and the lungs were then perfused at a rate of 2 $\mathrm{ml} / \mathrm{min}$. Collection of the effluent was started after a 5-min stabilization period. The perfusates were collected with an equal vol of $0.2 \mathrm{M}$ acetic acid containing the protease inhibitors to give a final concentration of $1 \mathrm{mg}$ EDTA $/ \mathrm{ml}, 10 \mu \mathrm{M}$ PMSF, and $5 \mu \mathrm{M}$ pepstatin A. The ANF immunoreactivity was measured in the perfusate by RIA after prior extraction on Sep-Pak cartridges.

Radioreceptor assay. The biological activity of ANF isolated from hamster lung perfusate was assessed by radioreceptor assay using rat kidney glomerular membranes (21). Rat glomerular membranes were prepared in $0.05 \mathrm{M}$ Tris- $\mathrm{HCl}$ buffer, $\mathrm{pH} 7.4$, containing $1 \mu \mathrm{M}$ aprotinin (No. 817113; Miles Laboratories, Inc., Elkhart, IN), $0.1 \%$ bacitracine (No. 80125; Sigma Chemical Co.), $500 \mu \mathrm{M}$ PMSF, $5 \mathrm{mM}$ $\mathrm{MgCl}_{2}$, and BSA (lot 405; Miles Laboratories, Inc.). Synthetic (Arg 101-Tyr 126) ANF was labeled with $I^{125}$ by the lactoperoxidase method and the tracer was purified by RP-HPLC. Specific activity of the tracer was $\simeq 950 \mu \mathrm{Ci} / \mu \mathrm{g}$. Membrane proteins $(35 \mu \mathrm{g}$ in $50 \mu \mathrm{l})$ were incubated with $\simeq 10,000 \mathrm{cpm}{ }^{125} \mathrm{I}-\mathrm{ANF}$ in the presence of cold ANF (6-6250 $\mathrm{pg} / \mathrm{ml}$ ) or serial dilution of hamster lung perfusate HPLC fraction for 1 $\mathrm{h}$ at room temperature in a total vol of $1 \mathrm{ml}$.

The membrane-bound tracer was separated by filtration on GF/C paper (Whatman Laboratory Products Inc., Clifton, NJ). The filters were washed twice with $3 \mathrm{ml} 0.05 \mathrm{M}$ Tris- $\mathrm{HCl}, \mathrm{pH} 7.4$, and counted in a gamma counter (LKB Instruments, Inc.).

\section{Results}

ANF content in atria, lung, and plasma of cardiomyopathic and control hamsters. Pulmonary and atrial ANF were determined in homogenates by direct RIA (14). Dilution curves of

Table I. ANF Content in Plasma, Lungs, and Atria of Manual and Cardiomyopathic Hamsters

\begin{tabular}{|c|c|c|c|c|c|c|}
\hline & \multirow[b]{2}{*}{ Age } & \multirow[b]{2}{*}{$n$} & \multirow{2}{*}{$\begin{array}{c}\text { Plasma ANF } \\
(\mathrm{pg} / \mathrm{ml})\end{array}$} & \multirow{2}{*}{$\begin{array}{c}\text { Lung ANF } \\
\text { ng/hamster } \\
\text { (ng/mg protein) }\end{array}$} & \multicolumn{2}{|c|}{$\begin{array}{c}\text { Atrial ANF } \\
\mu \mathrm{g} / \mathrm{hamster} \\
(\mu \mathrm{g} / \mathrm{mg} \text { protein })\end{array}$} \\
\hline & & & & & Right & Left \\
\hline & $d$ & & & & & \\
\hline Control & 240 & 8 & $25.7 \pm 8.5$ & $\begin{array}{c}16.1 \pm 1.5 \\
(0.44 \pm 0.04)\end{array}$ & $\begin{array}{c}1.78 \pm 0.12 \\
(0.90 \pm 0.05)\end{array}$ & $\begin{array}{c}1.04 \pm 0.04 \\
(0.54 \pm 0.03)\end{array}$ \\
\hline Control & 270 & 8 & $22.3 \pm 8.4^{*}$ & & & \\
\hline Cardiomyopathy & 106 & 8 & $85.8 \pm 14.9^{* \ddagger}$ & & & \\
\hline Cardiomyopathy & 163 & 8 & $150.1 \pm 30.9^{\ddagger}$ & $\begin{array}{c}35.1 \pm 8.3^{\ddagger} \\
(0.96 \pm 0.25)\end{array}$ & $\begin{array}{c}1.36 \pm 0.04^{\ddagger} \\
(0.64 \pm 0.03)\end{array}$ & $\begin{array}{c}0.76 \pm 0.06^{\ddagger} \\
(0.40 \pm 0.14)\end{array}$ \\
\hline Cardiomyopathy & 217 & 6 & $238.3 \pm 31.7^{* \neq}$ & & & \\
\hline Cardiomyopathy & 252 & 6 & $269.2 \pm 52.8^{\ddagger}$ & $\begin{array}{r}64.7 \pm 10.6^{\ddagger} \\
(2.1 \pm 0.04)\end{array}$ & $\begin{array}{c}0.98 \pm 0.14^{\ddagger} \\
(0.40 \pm 0.07)\end{array}$ & $\begin{array}{c}0.68 \pm 0.04^{\ddagger} \\
(0.37 \pm 0.11)\end{array}$ \\
\hline Cardiomyopathy & 272 & 6 & $310.0 \pm 29.7^{* \neq}$ & & & \\
\hline
\end{tabular}

Values are expressed as mean \pm SE. Please note the differences in units between lung (nanograms/milligram protein) and atrial (micrograms/ milligram protein) ANF values. ${ }^{*}$ The lungs and atria of these animals were processed for measurement of ANF mRNA. ${ }^{\ddagger} P<0.001$ as compared with control animals. 
pulmonary and atrial homogenates of control and cardiomyopathic hamsters were parallel to the RIA standard curve, indicating that the homogenates contain a peptide indistinguishable from synthetic ANF. As shown in Table I, the total atrial content of ANF was significantly lower in the animals with moderate cardiomyopathy, and decreased further in animals with severe heart failure. The concentration of ANF as expressed in micrograms per milligram protein was also lower, while the plasma content increased with the development of the disease to $\sim$ 14-fold higher in severe heart failure. In contrast to atrial ANF, total lung ANF content was increased twofold in the moderate state of the disease and fourfold in heart failure.

Molecular forms of ANF in plasma and tissues of cardiomyopathic and control hamsters. To confirm that increased lung ANF was due to increased peptide synthesis in the lung

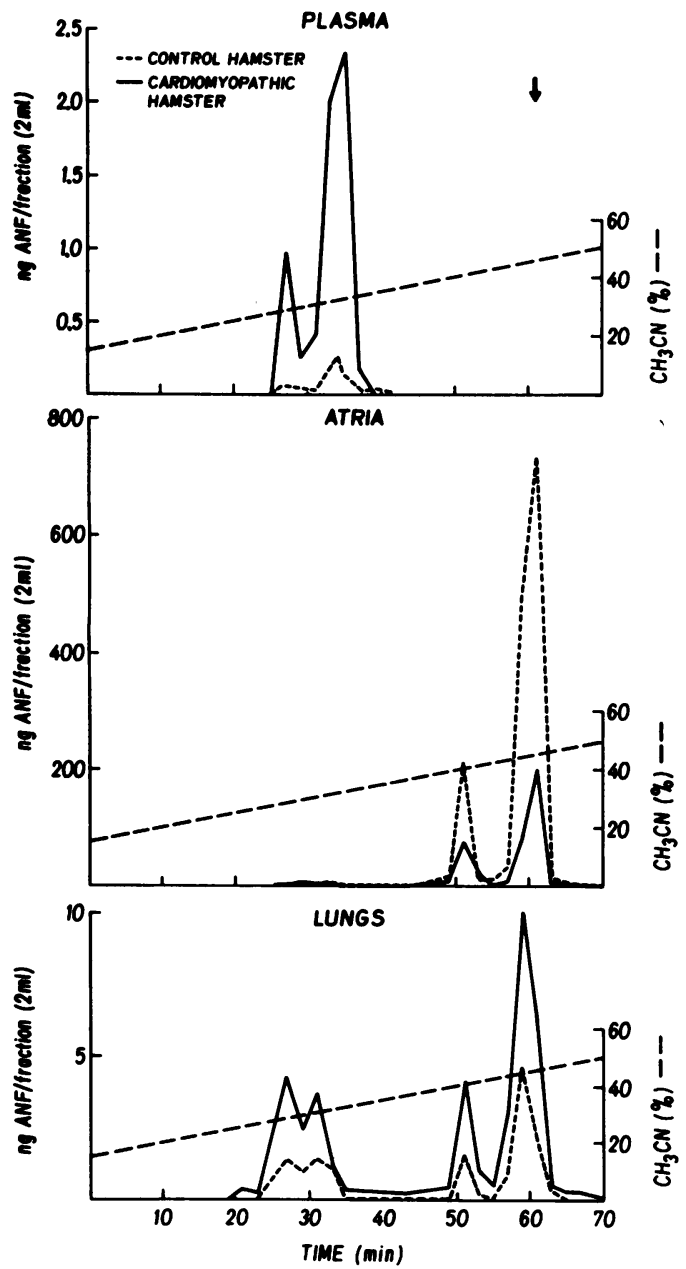

Figure 1. RP-HPLC analysis of plasma, lung, and atrial tissue. Plasma ANF was extracted by heat-activated Vycor glass beads and lung and atrial tissue homogenates were extracted on Sep-Pak cartridges. The plasma and tissue extracts were applied on $\mathrm{C}_{18-\mu \mathrm{m}}$ Bondapak column $(3.9 \mathrm{~mm} \times 30 \mathrm{~cm})$ in a HPLC system (LKB Instruments, Inc.). The column was developed at a flow rate of $1 \mathrm{ml} / \mathrm{min}$ using an acetonitrile gradient $15-50 \%$ in $0.1 \%$ TFA. The elution profile was monitored at $215 \mathrm{~nm}$ (not shown). The abscissa is marked at 10-min intervals. The arrow indicates the elution time of purified rat 126 amino acid prohormone (ANF 1-126). The 100- $\mu$ l eluates were evaporated to dryness in Speed-Vac and ANF was determined directly by RIA.

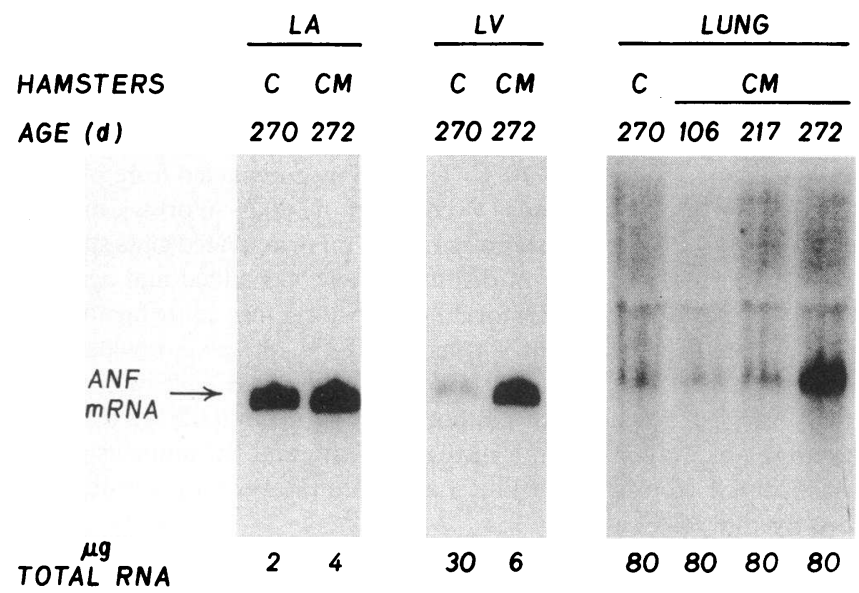

Figure 2. Northern blot analysis of ANF mRNA in atria, ventricles, and lung of control $(C)$ and cardiomyopathic $(C M)$ hamsters. The amount of total RNA is indicated for each lane. Total RNA was quantitated using ultraviolet spectroscopy and the amount of mRNA was quantitated by hybridization to oligo(dT) $)_{12-18}$ as described in Methods. The amount of RNA in the four lung samples was identical as further assessed by rehybridization of the same blot with a $\beta$ actin probe as detailed in Methods.

and was not the result of increased uptake of circulating ANF by high affinity binding sites in lung epithelium (22), we analyzed the molecular weight forms of lung ANF. The HPLC elution pattern of plasma, atrial, and pulmonary extracts is shown in Fig. 1. Multiple forms of ANF in cardiomyopathic hamster lungs are observed. Two of the peaks were identified, by comparison of elution time, as the 126 amino acid prohormone (Asn 1-Tyr 126) and the 28 amino acid circulating peptide (Ser 99-Tyr 126). The other peaks may be degradation products, although their identity is unknown at this time.

Tissue ANF $m R N A$. To determine if increased lung ANF was due to enhanced ANF gene expression, we measured ANF mRNA in lung tissue and compared it with atrial ANF mRNA content. As shown in Fig. 2, ANF mRNA in lung is not detectably changed in cardiomyopathic hamsters at the onset of development of hypertrophy ( $106 \mathrm{~d}$ old). With progression of the disease, ANF mRNA increased in the lung; in cardiomyopathic animals who have developed cardiac hypertrophy but are not in congestive heart failure, pulmonary ANF mRNA increased twofold. Lung ANF mRNA was greatest (fivefold increase over control) in animals ( $272 \mathrm{~d}$ old) who were in congestive heart failure. In contrast, atrial ANF mRNA levels are slightly decreased (40\%) in the same cardiomyopathic animals as compared with the controls, while ventricular ANF mRNA is significantly increased as previously reported (9).

Hamster lung perfusion. To examine the secretion of ANF from lungs, the perfusion of this organ was performed. As shown in Fig. $3 A$, ANF was released in a time-dependent manner during a 60-min perfusion of cardiomyopathic and normal hamster lungs. The HPLC pattern of cardiomyopathic hamster lung perfusates was identical to the pattern of plasma ANF (Fig. $3 \mathrm{~B}$ ). We further tested the biological activity of lung-produced ANF by its ability to displace ${ }^{125} \mathrm{I}$-ANF from rat glomerular receptors (21). The ANF purified from cardiomyopathic hamster lung perfusates did indeed compete in a dose-dependent manner with ${ }^{125} \mathrm{I}$-ANF for rat glomerular receptors (Fig. 4), suggesting that it possesses the potential for full biological activity. 

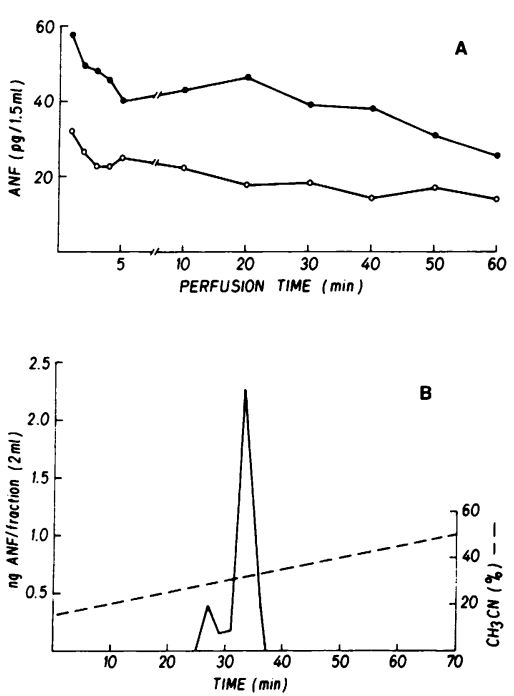

Figure 3. (A) Effect of perfusion time on ANF release by representative hamster lungs. $1.5 \mathrm{ml}$ of each 2-ml fraction of lung effluent was extracted by Sep-Pak cartridges and ANF was measured in the extracts by RIA. $\bullet$, cardiomyopathic hamsters; $O$, control. (B) Representative RP-HPLC performed on pool of effluent of cardiomyopathic hamster lungs. The $\mathrm{C}_{18}-\mu \mathrm{m}$ Bondapak column $(3.9 \mathrm{~mm} \times 30$ $\mathrm{cm}$ ) was eluted with the $15-50 \%$ acetonitrile gradient in $0.1 \%$ TFA. The immunoreactive ANF was determined in 100 $\mu \mathrm{l}$ of each fraction directly by RIA

\section{Discussion}

The results presented in this paper clearly show that lungs synthesize an increased amount of authentic ANF in a model of genetic cardiomyopathy, particularly during the development of congestive heart failure. During the development of disease, atrial ANF synthesis is diminished while plasma ANF is increased. This is accompanied by an increased content of lung ANF. Our study of the molecular forms of ANF present in the lungs shows that the main form is a 126 amino acid prohormone (Asn 1-Tyr 126). Since the circulating peptide is mainly a 28 amino acid fragment, the presence of a large proportion of prohormone in lungs rules out the possibility that increased pulmonary ANF content is simply due to increased

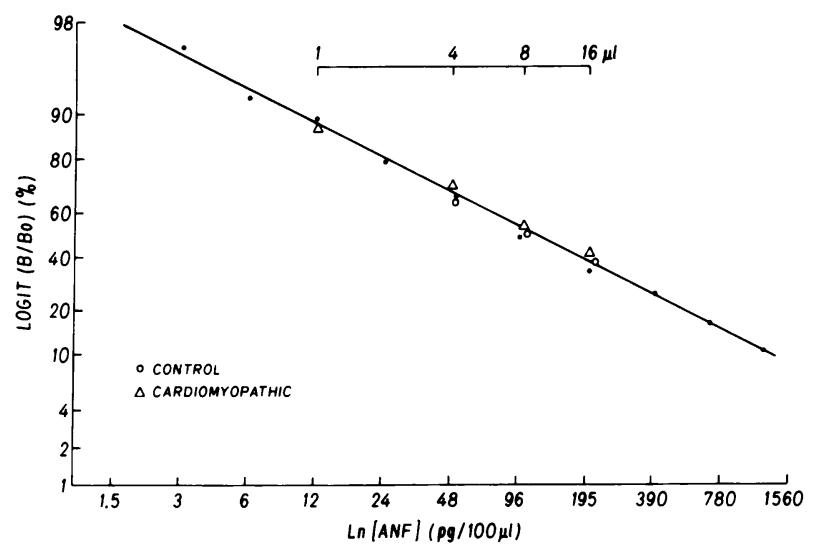

Figure 4. Representative standard curve for radioreceptor assay using rat kidney glomerular membranes expressed as logit B/Bo vs. ANF concentration. Bo is the radioactivity bound to the membrane receptors. $\mathrm{B}$ is the radioactivity bound to the receptors in the presence of known quantity of ANF standards. $\triangle$, Serial dilution $(1,4,8,16 \mu \mathrm{l})$ of HPLC fraction (eluted with $33 \%$ acetonitrile) from cardiomyopathic hamster lung perfusates.

uptake from the circulation. Furthermore, we tested directly whether increased peptide content reflects increased ANF gene expression by measuring mRNA in atria and lungs of control and cardiomyopathic hamsters. Changes in mRNA levels closely paralleled changes in peptide concentrations. Increases in lung ANF mRNA were detected after the onset of cardiomyopathy and were greatest in congestive heart failure. Before cardiac decompensation, at $106 \mathrm{~d}$ of age, there was little change in ANF mRNA levels in the lung. With development of cardiomyopathy, ANF peptide content (examined at $163 \mathrm{~d}$ of age) and ANF mRNA levels (at $217 \mathrm{~d}$ ) were increased twofold. When the animals were in congestive heart failure (252 and $272 \mathrm{~d}$ of age) both ANF mRNA and peptides were increased four- to fivefold. These data indicate that the expression of the ANF gene in the lung of genetically cardiomyopathic hamsters is not altered until development of hemodynamic changes that accompany the cardiomyopathic process.

In the lung of animals with congestive heart failure, ANF mRNA and peptide concentrations are 100-fold lower than in atria; however, since the mass of lung tissues is at least 50-fold greater than atrial tissues, the lungs may produce amounts of ANF similar to those produced in atria and thus contribute to the elevated levels of plasma ANF in these animals. The observation that authentic ANF can be secreted from lungs strengthens this hypothesis. It is important to mention that ANF gene expression is increased also in the ventricles of cardiomyopathic hamsters (12). However, the exact contribution of ventricles to plasma ANF remains to be established and the physiological significance of increased ANF mRNA in diseased ventricles is being investigated.

The differential control of ANF gene expression in atria and extraatrial tissues, particularly in lungs, is intriguing and may be attributed to a differential response of the two tissues to changes in hormonal and neuronal activities. Indeed, the early phase of congestive heart failure is associated with increased sympathetic activity (23) and a reduced capacity to excrete water or salt (24) that may be due to impairment of cardiac ANF secretion. The increase in pulmonary ANF production may be a compensatory response to sympathetic stimulation and to the decrease in atrial ANF secretion. This response may play a protective role in preventing further increases in peripheral vascular resistance by increasing the level of plasma ANF.

Alternatively, stimulated synthesis of ANF in the lungs may have a physiologically important paracrine function in preventing pulmonary edema that develops in conditions of congestive heart shock, renal disease, and lung infections. In support of this hypothesis, two studies have recently shown that administration of ANF can prevent experimentally induced pulmonary edema $(25,26)$. Thus, during cardiac dysfunction, extraatrial tissues like lungs may play an integral part in regulating body fluid volume and electrolyte balance by increasing their production and secretion of biologically active ANF. This is a first observation of metabolic changes in the lungs in experimental cardiomyopathy.

\section{Acknowledgments}

The authors thank Dr. Vincent Castellucci for his comments, Micheline Vachon, Jean-Pierre Lavigne, and Diane Miron for excellent technical assistance, and Nicole Guay-Poirier and Claudine Jutras for secretarial help. 
This work was supported by grants from the Medical Research Council of Canada, the Canadian Heart Foundation and l'Association Pulmonaire du Québec.

\section{References}

1. Buggy, J., and A. K. Johnson. 1977. Preoptic-hypothalamic periventricular lesions: thirst deficits and hypernatremia. Am. J. Physiol. 233:R44-R52.

2. de Bold, A. J. 1985. Atrial natriuretic factor: a hormone produced by heart. Science (Wash. DC). 230:767-770.

3. Cantin, M., and J. Genest. 1985. The heart and atrial natriuretic factor. Endocr. Rev. 6:107-127.

4. Gutkowska, J., and M. Nemer. 1988. ANF in extra-atrial tissues. In: Atrial Natriuretic Factor: Its Physiology and Biochemistry. Rev. Physiol. Biochem. Pharmacol. 110:25-30.

5. Gutkowska, J., M. Cantin, J. Genest, and P. Sirois. 1987. Release of immunoreactive atrial natriuretic factor from the isolated perfused rat lung. FEBS (Fed. Eur. Biochem. Soc.) Lett. 214:17-20.

6. Gardner, D. G., G. P. Vlasuk, J. D. Baxter, J. C. Fiddes, and J. A. Lewicki. 1987. Identification of atrial natriuretic factor gene transcripts in the central nervous system of the rat. Proc. Natl. Acad. Sci. USA. 84:2175-2179.

7. Homburger, F., C. W. Nixon, M. Eppenberger, and J. R. Baker. 1966. Hereditary myopathy in the Syrian hamster: studies on pathogenesis. Ann. NY Acad. Sci. 138:14-27.

8. Chimoskey, J. E., W. S. Spielman, M. A. Brandt, and S. R. Heidemann. 1984. Cardiac atria of BIO 14.6 hamsters are deficient in natriuretic factor. Science (Wash. DC). 233:820-821.

9. Nemer, M., J.-P. Lavigne, and J. Drouin. 1987. Ventricles are a major site of ANF gene expression in congestive heart failure. J. Mol. Cell. Cardiol. 19(Suppl. IV):45.

10. Franch, H. A., L. T. Callahan, and E. H. Blaine. 1986. Plasma and atrial content of atrial natriuretic factor in cardiomyopathic hamsters. Life Sci. 39:1151-1159.

11. Edwards, B. S., D. M. Ackermann, T. R. Schwab, D. M. Heublein, W. D. Edwards, L. E. Wold, and J. C. Burnett, Jr. 1986. The relationship between atrial granularity and circulating atrial natriuretic peptide in hamsters with congestive heart failure. Mayo Clin. Proc. 61:517-521.

12. Edwards, B. S., D. M. Ackermann, M. E. Lee, G. S. Reeder, L. E. Wold, and J. C. Burnett, Jr. 1988. Identification of atrial natriuretic factor within ventricular tissue in hamsters and humans with congestive heart failure. J. Clin. Invest. 81:82-86.

13. Bishop, S. P., M. J. Sole, and M. P. Tilley. 1979. Cardiomyopathies. In Spontaneous Animal Models of Human Disease E. J. An- drews, B. C. Ward, and N. H. Altman, editors. Academic Press, Inc. Toronto. 59-64.

14. Gutkowska, J., G. Thibault, P. Januszewicz, M. Cantin, and J. Genest. 1984. Direct radioimmunoassay of atrial natriuretic factor. Biochem. Biophys. Res. Commun. 122:593-601.

15. Gutkowska, J., K. Hòrky, G. Thibault, and M. Cantin. 1984. Atrial natriuretic factor is a circulating hormone. Biochem. Biophys. Res. Commun. 125:315-323.

16. Gutkowska, J., M. Bourassa, D. Roy, G. Thibault, R. Garcia M. Cantin, and J. Genest. 1985. Immunoreactive atrial natriuretic factor (IR-ANF) in human plasma. Biochem. Biophys. Res. Commun. 128:1350-1357.

17. Nemer, M., J.-P. Lavigne, J. Drouin, G. Thibault, M. Gannon, and T. Antakly. 1986. Expression of atrial natriuretic factor gene in heart ventricular tissue. Peptides (NY). 7:1147-1152.

18. Zivin, R. A., J. H. Condra, R. A. Dixon, N. G. Seidah, M. Chrétien, M. Nemer, M. Chamberland, and J. Drouin. 1984. Molecular cloning and characterization of DNA sequences encoding rat and human atrial natriuretic factors. Proc. Natl. Acad. Sci. USA. 81:63256329.

19. Farmer, S. R., K. M. Wan, A. Ben-Ze'ev, and S. Penman. 1983 Regulation of actin mRNA levels and translocation responds to changes in cell configuration. Mol. Cell. Biol. 3:182-189.

20. Engineer, D. M., V. Niederhauser, P. J. Piper, and P. Sirois. 1978. Release of mediators of anaphylaxis: inhibition of prostaglandin synthesis and modification of release of glow reacting substance of anaphylaxis and histamine. Br. J. Pharmacol. 62:61-66.

21. Gutkowska, J., F. Carrier, J. St. Louis, G. Thibault, M. Cantin, and J. Genest. 1988. Radioreceptor assay for atrial natriuretic factor. Anal. Biochem. 168:100-106.

22. Bianchi, C., J. Gutkowska, G. Thibault, R. Garcia, J. Genest, and M. Cantin. 1985. Radioautographic localization of ${ }^{125} \mathrm{I}$-atrial natriuretic factor (ANF) in rat tissues. Histochemistry. 82:441-452.

23. Sole, M. J., C. M. Lo, C. W. Laird, E. H. Sonnenblick, and R. J. Wartman. 1979. Norepinephrine turnover in the heart and spleen of the cardiomyopathic Syrian hamster. Circ. Res. 37:855-862.

24. McMurray, J., and A. D. Struthers. 1987. The role of neuroendocrine abnormalities in the enhanced sodium and water retention of chronic heart failure. Pharmacol. \& Toxicol. 61:209-214.

25. Inomata, N., N. Ohnuma, M. Furuya, Y. Hayashi, Y. Kanai, T. Ishihara, T. Noguchi, and H. Matsuo. 1987. Alpha-human atrial natriuretic peptide ( $\alpha$-hANP) prevents pulmonary edema induced by arachidonic acid treatment in isolated perfused lung from guinea pig. Jpn. J. Pharmacol. 44:211-214.

26. Imamura, T., M. Ohnuma, F. Iwasa, M. Furuya, Y. Hayashi, N. Inomata, T. Ishira, and T. Noguchi. 1984. Protective effect of $\alpha$-human atrial natriuretic polypeptide ( $\alpha$-hANP) on chemical-induced pulmonary edema. Life Sci. 42:403-414. 